\title{
THE EFFECTS OF EXOGENOUS AMINO ACID ON GROWTH, IONIC HOMEOSTASIS, BIOCHEMICAL COMPOSITION AND ANTIOXIDATIVE ACTIVITY OF GUAR (CYAMOPSIS TETRAGONOLOBA (L.) TAUB.) SEEDLINGS
}

\author{
KUSVURAN, A. ${ }^{*}-$ KAYTEZ, I. A. ${ }^{2}-$ YILMAZ, U. $^{3}-$ KUSVURAN, S. ${ }^{1}$ \\ ${ }^{1}$ Cankiri Karatekin University, Kizilirmak Vocational High Scholl, Cankiri, Turkey \\ (phone: +90-376-324-1018; fax: +90-376-324-1048) \\ ${ }^{2}$ Cankiri Karatekin University, Institute of Natural and Applied Science, Cankiri, Turkey \\ (phone: +90-376-324-1018; fax: +90-376-324-1048) \\ ${ }^{3}$ Cankiri Karatekin University, Faculty of Forestry, Cankiri, Turkey \\ (phone: +90-376-212-2757; fax: +90-376-213-6983) \\ *Corresponding author \\ e-mail: akusvuran@gmail.com; phone: +90-376-324-1018; fax: +90-376-324-1048
}

(Received $1^{\text {st }}$ Aug 2019; accepted $31^{\text {st }}$ Oct 2019)

\begin{abstract}
Amino acids, being the primary products of inorganic assimilation and precursors of proteins, play an essential role in plant metabolism. The objective of this study was to compare guar plants which were grown under salt-stress conditions $(150 \mathrm{mM} \mathrm{NaCl})$, in terms of the effect of different amino acid treatments (300,600,1200, and $1800 \mathrm{mg} \mathrm{L}^{-1}$ amino acid) on physiological, morphological, and enzymatic activity. Amino acid (AA) applications significantly increased fresh and dry weight, relative water content, photosynthetic pigments, total phenolic, flavonoid and free amino acid contents, $\mathrm{K}^{+}$and $\mathrm{Ca}^{++}$ion concentration, ascorbate peroxidase (APX), catalase (CAT), glutathione reductase (GR), and superoxide dismutase (SOD) activity of guar plants compared to the salt stress treatment the ones under no AA treatment. According to the results, the malondialdehyde (MDA) content, $\mathrm{Na}^{+}$and $\mathrm{Cl}^{-}$ion contents were significantly decreased. Hence, the results support the application of the amino acid in $600 \mathrm{mg} \mathrm{L}^{-1}$ doses in order to increase the defense system of the guar plant, enabling it to tolerate the negative effects induced by salinity.
\end{abstract}

Keywords: biostimulant, cluster bean, enzyme activity, ion regulation, oxidative stress, seconder metabolite

\section{Introduction}

Salinity is a significant abiotic stress factor that threatens agriculture in both arid and semiarid environments, affecting over $20 \%$ of the world's irrigated land (Wu et al., 2017). Salt stress induces changes in a plant's biochemical, physiological, and morphological responses resulting in reduced growth, yield, biomass, and quality of crop plants.

Salinity in growth mediums have an unfavorable impact on the growth of plants and their development, which could presumably be the result of the presence of salt in the soil, thus reducing the plant's water uptake (low osmotic potential), resulting in high levels of salt entering the plant via transpiration, which causes damage to the transpiring leaf cells (specific ion toxity) (Parihar et al., 2015; Rady et al., 2018).

Salt stress, like other environmental stresses, induces the accumulation of reactive oxygen species (ROS) such as hydrogen peroxide $\left(\mathrm{H}_{2} \mathrm{O}_{2}\right)$, superoxide $\left(\mathrm{O}_{2}{ }^{-}\right)$, and hydroxyl radicals (OH-) (Sekmen et al., 2013). Increased ROS concentration causes 
oxidative damage for plant tissues in various ways (e.g., decrease in chlorophyll content, damage to cell membrane, protein oxidation, strand breaks in nucleic acids, etc.), leading finally to cell death. The degree of stress injuries to plants is reflected by membrane permeability. Furthermore, ROS levels above threshold cause lipid peroxidation (LPO) in both cellular and organelle membranes, which not only directly affects cellular functioning, but also aggravates the oxidation stress through the production of lipidderived radicals (Patel et al., 2013). In response to salinity, plants have developed a series of enzymatic (e.g., super oxide dismutase (SOD), catalase (CAT), ascorbate peroksidase (APX), glutathione reductase (GR) and several peroxidases) and non-enzymatic (ascorbate, carotenoids, flavonoids and other phenolic compounds etc.) detoxification systems to counteract reactive oxygen species, and protect cells from oxidative damage (Taibi et al., 2016). SOD converts $\mathrm{O}_{2}^{-}$to $\mathrm{H}_{2} \mathrm{O}_{2}$, which is detoxified to water and oxygen by CAT, POX, and APX. SOD is localized in almost all cellular compartments and the water-water cycle in chloroplasts. The components of the ascorbate-glutathione cycle are localized in chloroplasts, cytosol, mitochondria, and apoplast, while both glutathione peroxidase (GPX) and CAT are localized in peroxisomes (Sekmen et al., 2013).

Plants have developed various approaches to reduce the negative effects resulting from abiotic stressors, several of which have been related to the metabolism of amino acids (Batista Silva et al., 2019). They have improved the ability to physiologically and/or behaviorally respond and adapt to environmental stressors through organic solute accumulation or ion movement control, which enables the increase of solute concentrations at the intracellular level. Osmotic adjustment involves the accumulation of low molecular weight compounds in the cytosol, compatible osmolytes, which do not interfere with normal biochemical reactions (De Freitas et al., 2018) and these osmolytes that do not interfere with plant metabolism even at high concentrations and may also act as ROS scavengers (Batista Silva et al., 2019). Amino acids are organic nitrogenous compounds that are the building blocks in the synthesis of proteins (Sarojnee et al., 2009). El-Din et al. (2005) reported that, in higher plants, amino acids have the ability to behave like growth factors, because they are protein synthesis building blocks, and may be enzymes significant for metabolic activity. These components are particularly important for cell growth stimulation, because they behave like buffers that aid in maintaining an appropriate $\mathrm{pH}$ value in plant cells. Moreover, because they comprise both acidic and basic groups, they are able to aid in ammonia removal within the cell (Nahed et al., 2010). Furthermore, amino acids assist in the synthesis of various organic compounds, including alkaloids, amines, enzymes, terpenoids, proteins, purines and pyrimidines, vitamins, etc. (Talaat et al., 2014).

Cluster bean, or Guar, has gained an important commercial status as a result of its gum and is now the most significant product exported in the farming sector, due to it being a cash crop that is highly-valued in both arid and semi-arid areas because of its tolerance to drought and vast array of uses (Pathak, 2015).

It has been reported that amino acids that were applied exogenously to plants exposed to abiotic stressors brought about a preventive or recovery effect. Therefore the following two hypotheses were tested: 1) the effect of AA concentrations on the growth, and 2) how AA reveal a change in biochemical composition, ion regulation and oxidative status in guar seedlings. 


\section{Materials and methods}

The study was conducted at an experimental site of Cankiri Karatekin University in Turkey. For this experiment, a mixture of peat:perlite substrate $(2: 1)$ was used to germinate the guar seeds, which were then housed in a greenhouse kept at day/night temperatures of $26 \pm 2{ }^{\circ} \mathrm{C}$ and $18 \pm 2{ }^{\circ} \mathrm{C}$, and a relative humidity of $65 \% \pm 5$. Growth chamber and nutrient solution (following that of Dasgan and Koc, 2009) irrigation was used to grow the plants. Each pot contained 5 plants and each of the 3 replications also every treatment included 5 pots (total 90 pots). According to our previous studies were determined $\mathrm{NaCl}$ doses (data not shown). Starting from 39 days of after sowing (DAS), the saline treatment began with $50 \mathrm{mM} \mathrm{NaCl}$ on the first day and was increased by $50 \mathrm{mM}$ $\mathrm{NaCl}$ each day until the $2^{\text {th }}$ day, where it reached $150 \mathrm{mM} \mathrm{NaCl}$. For this experiment, the amount of water applied was calculated based on the ratio of water drained: water applied (Schubert and Lauchli, 1990). In the control plant were not exposed to saline stress. Amino acid treatments were added in the irrigation water with salinity treatments. The commercial product "Amino gold" was used as a source of amino acids and it contains $29 \%$ free L. amino acids, $70 \%$ total organic matter, $14 \%$ organic carbon, 3\% organic nitrogen, $20 \%$ humidity and 2.5-4.5 $\mathrm{pH}$. The experiment involved the following treatments; 1) control (nutrient solution irrigation void of $\mathrm{NaCl})(\mathrm{C}), 2)$ Salts treatments (salinity at $150 \mathrm{mM} \mathrm{NaCl}$ ) (S), 3) Salinity+300 $\mathrm{mg} \mathrm{L}^{-1}$ amino acid (AA1), 4) Salinity+600 $\mathrm{mg} \mathrm{L}^{-1}$ amino acid (AA2), 5) Salinity+1200 $\mathrm{mg} \mathrm{L}^{-1}$ amino acid (AA3), 6) Salinity+1800 $\mathrm{mg} \mathrm{L}^{-1}$ amino acid (AA4).

The end of the experiment (61 DAS), plants were evaluated using some plant physiological (shoot fresh and dry weights, shoot diameter, shoot length, and number of leaves and leaf area per plant, relative water content (RWC), photosynthetic pigments (Chl-a, Chl-b, total carotenoid), $\mathrm{Na}^{+}, \mathrm{K}^{+}, \mathrm{Ca}^{2+}$, and $\mathrm{Cl}^{-}$ions content) and biochemical parameters such as total phenolic content (TPC), flavonoids, total free amino acid, and lipid peroxide content (malondialdehyde, MDA); ascorbat peroxidase (APX), catalase (CAT), glutathione reductase (GR), superoxide dismutase (SOD), and antioxidative enzyme activities.

For ion determination, the plants were harvested and dried at $65^{\circ} \mathrm{C}$ for $48 \mathrm{~h}$. The leaves of were burned at $550^{\circ} \mathrm{C}$, and dissolved in $1 \%(\mathrm{v} / \mathrm{v})$ hydrochloric acid, and then analyzed for $\mathrm{Na}^{+}, \mathrm{K}^{+}$, and $\mathrm{Ca}^{2+}$ using an atomic absorption spectrometer (Varian Spectra AA 220 FS). The $\mathrm{Cl}$ concentration was determined using the Mohr method (Dasgan and Koc, 2009).

Determination of the chlorophyll $(\mathrm{Chl}) \mathrm{a}$ and $\mathrm{b}$ and contents were done according to the method of Arnon (1949). Extraction of the leaf pigment was done using 80\% (v/v) acetone and the extraction absorbance was measured with a spectrophotometer (Shimadzu UVmini-1240; Shimadzu Corporation, Kyoto, Japan) at 663, 645, and $470 \mathrm{~nm}$. The total phenolic content was determined using a Folin-Ciocalteu reagent. The phenolic content of leaves and stems was expressed in milligrams. Gallic acid was used as a standard (Singleton et al., 1999). The colorimetric assay was used to establish the flavonoid content (Molina-Quijada et al., 2010; Medina-Juárez et al., 2012). Total flavonoids were expressed on a fresh weight (fw) basis as milligrams of quercetin equivalents per gram. Total free amino acid content was determined with the ninhydrin reagent method (Yemm and Cocking, 1955).

A mortar and pestle, along with an extraction buffer $(5 \mathrm{~mL})$ comprised of a potassiumphosphate buffer $(50 \mathrm{mM}, \mathrm{pH} 7.6)$ and disodium ethylene diamine tetra acetate $(0.1 \mathrm{mM})$ was used to extract the enzymes from $0.5 \mathrm{~g}$ of leaf tissue. After centrifugation of the 
homogenate at $15.000 \times \mathrm{g}$ for $15 \mathrm{~min}$, the supernatant fraction was then used for the enzyme assay. All of the enzyme extraction preparation operations were carried out at $4^{\circ} \mathrm{C}$. Nitro blue tetrazolium (NBT) was used to reduce the superoxide radical, which was monitored at $560 \mathrm{~nm}$ to essay the SOD, according to the method of Karanlik (2001). Monitoring the disappearance of HO was used to determine the CAT activity, while measuring the ascorbate consumption from its absorbance at $290 \mathrm{~nm}$ was used to determine the APX activity. One unit of APX activity was determined as the amount of enzyme necessary to consume $1 \mu \mathrm{Mol}$ of ascorbate min $^{-1}$ (Cakmak and Marschner, 1992). Determination of the GR activity was performed via measurement of NADPH enzymedependent oxidation based on its absorbance at $340 \mathrm{~nm}$. One unit of GR activity was determined as the amount of enzyme necessary to oxidize $1 \mu \mathrm{Mol}$ of NADPH min ${ }^{-1}$.

The amount of MDA ascertained via the thiobarbituric acid reaction was used to measure the lipid peroxidation (Heath and Packer, 1968). The calculation of the MDA content was based on the MDA molar extinction coefficient; $155 \mathrm{mM}^{-1} \mathrm{~cm}^{-1}$.

The experimental plot design was randomized, comprising 3 replications. A comparison of the parameter mean values was performed via the least significant difference test. Statistical significance was determined as $p<0.05$ using JMP statistical software, ver. 5.1 (SAS Institute Inc., USA). Data are presented as the mean \pm standard deviation. and in all figures error bars are representing standard errors of the means.

\section{Results}

An improvement value in growth parameters of the guar plants which were grown under saline conditions by using amino acids is shown in Table 1. Guar plants were treated with $\mathrm{NaCl}$ and these values were reduced by $41-87 \%$, respectively, compared to the control. However, amino acid applications under salt stress significantly enhanced the growth components such as shoot fresh and dry weight, shoot length, shoot diameter, number of leaves per plant, leaf area per plant, compared to the salt-stressed groups. These reactions changed between $16-67 \%$ ratios. When compared to S, S+AA enhanced the amelioration for growth by $39-392 \%$. Among to these applications the highest effect was determined in AA2 and the improvement was identified by $76-883 \%$.

Table 1. Effects of AA applications on growth parameters of guar plants under saline condition (C: control; S: salt stress (150 mM NaCl); AAl: $150 \mathrm{mM} \mathrm{NaCl+300} \mathrm{mg} \mathrm{L}^{-1}$ amino acid; AA2: $150 \mathrm{mM} \mathrm{NaCl}+600 \mathrm{mg} \mathrm{L}^{-1}$ amino acid; $A A 3: 150 \mathrm{mM} \mathrm{NaCl}+1200 \mathrm{mg} \mathrm{L}^{-1}$ amino acid; AA4: $150 \mathrm{mM} \mathrm{NaCl}+1800 \mathrm{mg} \mathrm{L}^{-1}$ amino acid

\begin{tabular}{|c|c|c|c|c|c|c|}
\hline & $\begin{array}{c}\text { Shoot fresh } \\
\text { weight } \\
\left(\text { g plant }^{-1}\right) \\
\end{array}$ & $\begin{array}{c}\text { Shoot dry } \\
\text { weight } \\
\left(\text { g plant }^{-1}\right) \\
\end{array}$ & $\begin{array}{l}\text { Shoot length } \\
\left(\mathrm{cm} \mathrm{plant}^{-1}\right)\end{array}$ & $\begin{array}{c}\text { Shoot diameter } \\
\left(\mathrm{mm}^{-} \text {plant }^{-1}\right)\end{array}$ & $\begin{array}{c}\text { Steam Number } \\
\left(\text { num. plant }{ }^{-1}\right)\end{array}$ & $\begin{array}{c}\text { Leaf Area } \\
\left(\mathrm{cm}^{2} \text { plant }^{-1}\right)\end{array}$ \\
\hline $\mathrm{C}$ & $65.10 \pm 2.26^{b}$ & $24.74 \pm 2.42^{b}$ & $24.00 \pm 2.00^{b}$ & $5.08 \pm 0.72^{\mathrm{a}}$ & $9.67 \pm 1.53^{\mathrm{ab}}$ & $663.44 \pm 25.98^{\mathrm{a}}$ \\
\hline S & $9.05 \pm 3.27^{\mathrm{d}}$ & $3.35 \pm 1.21^{\mathrm{e}}$ & $13.00 \pm 2.65^{\mathrm{c}}$ & $2.33 \pm 0.28^{c}$ & $5.67 \pm 1.15^{\mathrm{b}}$ & $108.36 \pm 13.10^{\mathrm{d}}$ \\
\hline AA 1 & $27.62 \pm 3.65^{c}$ & $17.80 \pm 1.00^{c}$ & $14.67 \pm 2.52^{c}$ & $3.32 \pm 0.48^{\mathrm{bc}}$ & $8.67 \pm 1.51^{\mathrm{ab}}$ & $165.47 \pm 19.14^{\mathrm{cd}}$ \\
\hline AA2 & $82.33 \pm 5.53^{\mathrm{a}}$ & $32.95 \pm 2.22^{\mathrm{a}}$ & $27.33 \pm 1.15^{\mathrm{a}}$ & $5.70 \pm 0.57^{\mathrm{a}}$ & $10.00 \pm 2.00^{\mathrm{a}}$ & $420.91 \pm 37.88^{b}$ \\
\hline AA3 & $21.72 \pm 3.66^{\mathrm{c}}$ & $8.25 \pm 1.39^{\mathrm{d}}$ & $15.00 \pm 1.00^{c}$ & $2.69 \pm 0.39^{\mathrm{bc}}$ & $8.33 \pm 2.08^{\mathrm{ab}}$ & $221.53 \pm 12.34^{\mathrm{c}}$ \\
\hline AA4 & $19.48 \pm 4.98^{c}$ & $7.02 \pm 1.79^{d}$ & $15.33 \pm 0.58^{c}$ & $3.37 \pm 0.83^{\mathrm{b}}$ & $7.67 \pm 1.06^{\mathrm{ab}}$ & $145.72 \pm 15.01^{\mathrm{cd}}$ \\
\hline
\end{tabular}

* Each value represents the mean of three replicates. For each parameter of each different letters are significantly different at $\mathrm{p}<0.05$ according to LSD test 
Guar seedling treated with salt stress demonstrated a decrease in RWC at $44 \%$ ration, compared to control (Table 2). However, a significant improvement in the RWC of AA-treated plants was observed an increase 48, 60, 34, and 25\% in AA1, AA2, AA3, and AA4, respectively, compared to the plant that was treated with $150 \mathrm{mM} \mathrm{NaCl}$ solely $(\mathrm{p}<0.05)$. Under salt $(150 \mathrm{mM})$ stress, photosynthetic pigments such as total Chl-a, Chl-b, and total carotenoid were reduced by 43,47 , and $61 \%$, in guar plants, respectively (Table 2). Auxiliary addition of amino acids to the salt-stressed guar plants induced a significant increase in photosynthetic pigments by $8-46 \%, 37-96 \%$, and $54-143 \%$, compared to salinity conditions, respectively.

Table 2. Effects of AA applications on relative water content $(R W C)$ and photosynthetic pigments of guar under saline condition (C: control; S: salt stress (150 mM NaCl); AAl: 150 $\mathrm{mM} \mathrm{NaCl}+300 \mathrm{mg} \mathrm{L}^{-1}$ amino acid; $A A 2: 150 \mathrm{mM} \mathrm{NaCl}+600 \mathrm{mg} \mathrm{L}^{-1}$ amino acid; AA3: 150 $\mathrm{mM} \mathrm{NaCl}+1200 \mathrm{mg} \mathrm{L}^{-1}$ amino acid; AA4: $150 \mathrm{mM} \mathrm{NaCl}+1800 \mathrm{mg} \mathrm{L}^{-1}$ amino acid)

\begin{tabular}{c|c|c|r|r}
\hline & $\begin{array}{c}\text { RWC } \\
(\%)\end{array}$ & $\begin{array}{c}\text { Chl a } \\
\left(\mathbf{m g ~ g}^{-1} \mathbf{F W}\right)\end{array}$ & $\begin{array}{c}\text { Chl b } \\
\left(\mathbf{m g ~ g}^{-\mathbf{1}} \mathbf{F W}\right)\end{array}$ & $\begin{array}{c}\text { Total carotenoids } \\
\left(\mathbf{m g ~ g}^{-\mathbf{1}} \mathbf{F W}\right)\end{array}$ \\
\hline C & $97.36 \pm 2.00^{\mathrm{a}}$ & $2.26 \pm 0.10^{\mathrm{a}}$ & $1.61 \pm 0.15^{\mathrm{a}}$ & $1.14 \pm 0.08^{\mathrm{a}}$ \\
$\mathrm{S}$ & $54.35 \pm 1.99^{\mathrm{e}}$ & $1.28 \pm 0.16^{\mathrm{d}}$ & $0.89 \pm 0.06^{\mathrm{d}}$ & $0.44 \pm 0.07^{\mathrm{c}}$ \\
AA1 & $80.46 \pm 2.93^{\mathrm{bc}}$ & $1.87 \pm 0.10^{\mathrm{b}}$ & $1.43 \pm 0.05^{\mathrm{b}}$ & $0.67 \pm 0.03^{\mathrm{b}}$ \\
AA2 & $87.31 \pm 2.14^{\mathrm{b}}$ & $2.17 \pm 0.08^{\mathrm{a}}$ & $1.69 \pm 0.09^{\mathrm{a}}$ & $1.07 \pm 0.08^{\mathrm{a}}$ \\
AA3 & $72.57 \pm 2.11^{\mathrm{cd}}$ & $1.61 \pm 0.16^{\mathrm{c}}$ & $1.57 \pm 0.05^{\mathrm{ab}}$ & $0.74 \pm 0.12^{\mathrm{b}}$ \\
AA4 & $68.32 \pm 1.41^{\mathrm{d}}$ & $1.39 \pm 0.06^{\mathrm{d}}$ & $1.18 \pm 0.07^{\mathrm{c}}$ & $0.68 \pm 0.04^{\mathrm{b}}$ \\
\hline
\end{tabular}

* Each value represents the mean of three replicates. For each parameter of each different letters are significantly different at $\mathrm{p}<0.05$ according to LSD test

To confirm the salinity-induced oxidative stress conditions, intercellular levels of stress biomarker MDA were evaluated (Table 3). The MDA content was the lowest in control plants and increased significantly in $150 \mathrm{mM} \mathrm{NaCl}$ conditions. When compared to the control groups, the MDA levels increased by $189 \%\left(6.72 \mu \mathrm{mol} \mathrm{g}^{-1} \mathrm{FW}\right)$.

Table 3. Effects of AA applications on MDA content, total phenolic, flavonoid and free amino acid contents of guar under saline condition (C: control; $S$ : salt stress (150 mM NaCl); $A A 1$ : $150 \mathrm{mM} \mathrm{NaCl}+300 \mathrm{mg} \mathrm{L}^{-1}$ amino acid; AA2: $150 \mathrm{mM} \mathrm{NaCl}+600 \mathrm{mg} \mathrm{L}^{-1}$ amino acid; AA3: $150 \mathrm{mM} \mathrm{NaCl}+1200 \mathrm{mg} \mathrm{L}^{-1}$ amino acid; AA4: $150 \mathrm{mM} \mathrm{NaCl}+1800 \mathrm{mg} \mathrm{L}^{-1}$ amino acid)

\begin{tabular}{|c|c|c|c|c|}
\hline & $\begin{array}{c}\text { MDA } \\
\left(\mu \mathrm{mol} \mathrm{g}{ }^{-1} \mathrm{FW}\right)\end{array}$ & 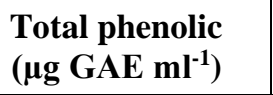 & 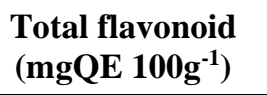 & $\begin{array}{l}\text { Total free amino acids } \\
\qquad\left(\mathrm{mg} \mathrm{g}^{-1} \mathrm{DW}\right)\end{array}$ \\
\hline $\mathrm{C}$ & $2.32 \pm 0.24^{\mathrm{d}}$ & $21.20 \pm 0.39^{\mathrm{d}}$ & $8.68 \pm 0.52^{\mathrm{d}}$ & $7.42 \pm 1.23^{\mathrm{c}}$ \\
\hline $\mathrm{S}$ & $6.72 \pm 0.26^{\mathrm{a}}$ & $16.99 \pm 0.43^{\mathrm{e}}$ & $11.68 \pm 1.41^{\mathrm{c}}$ & $9.90 \pm 0.65^{\mathrm{bc}}$ \\
\hline AA 1 & $4.19 \pm 0.17^{\mathrm{c}}$ & $22.76 \pm 1.34^{\mathrm{cd}}$ & $13.56 \pm 1.13^{b}$ & $11.42 \pm 1.02^{\mathrm{b}}$ \\
\hline AA2 & $3.46 \pm 0.18^{c}$ & $30.09 \pm 1.19^{\mathrm{a}}$ & $16.88 \pm 1.03^{\mathrm{a}}$ & $15.42 \pm 1.01^{\mathrm{a}}$ \\
\hline AA3 & $5.42 \pm 0.15^{\mathrm{b}}$ & $25.43 \pm 1.81^{\mathrm{bc}}$ & $16.31 \pm 0.89^{a}$ & $16.76 \pm 1.06^{\mathrm{a}}$ \\
\hline AA4 & $5.22 \pm 0.19^{b}$ & $26.71 \pm 1.68^{\mathrm{b}}$ & $13.83 \pm 0.67^{\mathrm{b}}$ & $19.05 \pm 2.33^{\mathrm{a}}$ \\
\hline
\end{tabular}

* Each value represents the mean of three replicates. For each parameter of each different letters are significantly different at $\mathrm{p}<0.05$ according to LSD test 
However, AA mitigated the stress effects on plants and further decreased the contents of MDA. In point of fact, through AA treatments, MDA content was decreased by 19$48 \%$ ratios. In addition to this, the lowest values were recorded at AA1 and AA2 treatments compared to with corresponding salinity.

Under salt stress, total phenolic and flavonoid contents decreased in guar (19 and 11\% decreases, respectively) compared to the control group (Table 3). Contrarily, AA treatments proved to result in a significant increase in the mean values of total phenolic and flavonoid contents, compared to both control group (23-74\% increase) and $150 \mathrm{mM}$ $\mathrm{NaCl}$ (54-97\% increase) individually. The maximum mean values were obtained in the AA2 application (30.09 $\mu \mathrm{gGAE} \mathrm{mL} \mathrm{m}^{-1}$ of total phenolic; $16.88 \mathrm{mgQE} 100 \mathrm{~g}^{-1}$ ) and with AA2 treatment in guar total phenolic and flavonoid contents demonstrated an increase between $77 \%$ and $45 \%$, compared to salinity conditions.

Total free amino acid content slightly increased with AAs applications, there after a constant increment in this content was recorded at AA1 (48\%), AA2 (108\%), AA3 (126\%), and AA4 (157\%) compared with untreated control (Table 3).

Compared to the control groups, salt stress increased the $\mathrm{Na}$ and $\mathrm{Cl}$ contents of all applications (320-545\% increase in $\mathrm{Na}$ and 571-890\% in $\mathrm{Cl}$ ) (Table 4). However, these values were clearer in without AA application under salt stress condition (Na: $3.10 \%$; $\mathrm{Cl}: 3.17 \%$ ). With AA application, salt-stressed plants accumulated less $\mathrm{Na}$ and $\mathrm{Cl}$, and these ion accumulations decreased by 16-18\% compared to the salt application only. On the contrary of toxic $\mathrm{Na}$ and $\mathrm{Cl}$ ions, $\mathrm{K}$ and $\mathrm{Ca}$ ion accumulation decreased in salt conditions. These reactions were determined as 52\% and 53\% under salt stress conditions, respectively. The AA applications alleviated the stress effects on these parameters and significantly increased the $\mathrm{K}$ and $\mathrm{Ca}$ contents, compared to $\mathrm{NaCl}$ contents. According to results, AA applications ensured an increase of the $\mathrm{K}$ content by $11-53 \%$ and $\mathrm{Ca}$ content by $23-70 \%$. Under salt stress, the best effect was determined in AA2 applications and in this treatment, $\mathrm{K}$ and $\mathrm{Ca}$ values increased by 53 and $70 \%$ compared to salt stress.

Table 4. Effects of $\mathrm{AA}$ applications on $\mathrm{Na}, \mathrm{K}, \mathrm{Ca}$ and $\mathrm{Cl}$ contents of guar under saline condition (C: control; S: salt stress (150 mM NaCl); AAl: $150 \mathrm{mM} \mathrm{NaCl+300} \mathrm{mg} \mathrm{L}^{-1}$ amino acid; AA2: $150 \mathrm{mM} \mathrm{NaCl}+600 \mathrm{mg} \mathrm{L}^{-1}$ amino acid; $A A 3: 150 \mathrm{mM} \mathrm{NaCl}+1200 \mathrm{mg} \mathrm{L}^{-1}$ amino acid; $A A 4: 150 \mathrm{mM} \mathrm{NaCl}+1800 \mathrm{mg} \mathrm{L}^{-1}$ amino acid)

\begin{tabular}{c|c|c|c|c}
\hline & $\mathbf{N a}(\boldsymbol{\%})$ & $\mathbf{K}(\boldsymbol{\%})$ & $\mathbf{C a}(\boldsymbol{\%})$ & $\mathbf{C l}(\boldsymbol{\%})$ \\
\hline C & $0.48 \pm 0.04^{\mathrm{d}}$ & $4.07 \pm 0.18^{\mathrm{a}}$ & $5.17 \pm 0.16^{\mathrm{a}}$ & $0.32 \pm 0.03^{\mathrm{e}}$ \\
S & $3.10 \pm 0.19^{\mathrm{a}}$ & $1.95 \pm 0.17^{\mathrm{d}}$ & $2.45 \pm 0.13^{\mathrm{f}}$ & $3.17 \pm 0.09^{\mathrm{a}}$ \\
AA1 & $2.71 \pm 0.16^{\mathrm{b}}$ & $2.18 \pm 0.04^{\mathrm{c}}$ & $3.03 \pm 0.12^{\mathrm{e}}$ & $2.90 \pm 0.11^{\mathrm{b}}$ \\
AA2 & $2.02 \pm 0.13^{\mathrm{c}}$ & $3.00 \pm 0.18^{\mathrm{b}}$ & $4.17 \pm 0.18^{\mathrm{b}}$ & $2.15 \pm 0.07^{\mathrm{d}}$ \\
AA3 & $2.66 \pm 0.09^{\mathrm{b}}$ & $2.43 \pm 0.17^{\mathrm{c}}$ & $3.72 \pm 0.21^{\mathrm{c}}$ & $2.70 \pm 0.08^{\mathrm{c}}$ \\
AA4 & $2.78 \pm 0.07^{\mathrm{b}}$ & $2.23 \pm 0.10^{\mathrm{c}}$ & $3.34 \pm 0.20^{\mathrm{d}}$ & $2.86 \pm 0.05^{\mathrm{b}}$ \\
\hline
\end{tabular}

* Each value represents the mean of three replicates. For each parameter of each different letters are significantly different at $\mathrm{p}<0.05$ according to LSD test

Antioxidative enzyme activity (SOD, CAT, GR, and APX) levels were evaluated in $\mathrm{C}, \mathrm{S}$, and S+AA treatments (Table 5). Salt stress caused an increase in SOD, CAT, GR and APX activities at different levels. It is evident from the figure that AA treatments had 
a serious effect on antioxidative enzyme activities such as SOD, CAT, GR, and APX of the guar seedlings under salt stress. In S+AA applications, enzyme activities (SOD, CAT, GR, and APX) increased by 9-48, 12-51, 14-112, and 14-129\%, compared to the $150 \mathrm{mM}$ treatment. In addition to these results, the highest enzyme activities were noted at AA2 treatment (SOD: $510.46 \mathrm{U} \mathrm{min}^{-1} \mathrm{mg}^{-1} \mathrm{FW}$; CAT: $637.26 \mu \mathrm{mol} \mathrm{min} \mathrm{mg}^{-1} \mathrm{FW}$; GR: $229.62 \mu \mathrm{mol} \mathrm{min}{ }^{-1} \mathrm{mg}^{-1} \mathrm{FW}$, APX: $220.19 \mu \mathrm{mol} \mathrm{min}^{-1} \mathrm{mg}^{-1} \mathrm{FW}$ ) compared with control and salinity.

Table 5. Effects of AA applications on SOD, CAT, GR, and APX enzyme activities of guar under saline condition (C: control; $S$ : salt stress (150 mM NaCl); AAl: $150 \mathrm{mM} \mathrm{NaCl+300}$ $m g L^{-1}$ amino acid; AA2: $150 \mathrm{mM} \mathrm{NaCl}+600 \mathrm{mg} \mathrm{L}^{-1}$ amino acid; $A A 3: 150 \mathrm{mM} \mathrm{NaCl}+1200$ $m g L^{-1}$ amino acid; AA4: $150 \mathrm{mM} \mathrm{NaCl}+1800 \mathrm{mg} \mathrm{L}^{-1}$ amino acid) (SOD $\mathrm{U} \mathrm{min}^{-1} \mathrm{mg}^{-1} \mathrm{FW}$; CAT, GR, APX: $\mu \mathrm{mol} \mathrm{min}^{-1} \mathrm{mg}^{-1} \mathrm{FW}$ )

\begin{tabular}{c|r|r|r|l}
\hline & SOD & CAT & GR & APX \\
\hline C & $68.74 \pm 10.96^{\mathrm{e}}$ & $122.67 \pm 18.75^{\mathrm{d}}$ & $29.44 \pm 5.29^{\mathrm{d}}$ & $18.62 \pm 2.80^{\mathrm{d}}$ \\
S & $342.90 \pm 54.92^{\mathrm{d}}$ & $419.63 \pm 23.32^{\mathrm{c}}$ & $45.63 \pm 2.43^{\mathrm{c}}$ & $25.95 \pm 4.29^{\mathrm{c}}$ \\
AA1 & $424.18 \pm 19.57^{\mathrm{bc}}$ & $469.23 \pm 22.26^{6 \mathrm{c}}$ & $59.82 \pm 6.95^{\mathrm{b}}$ & $49.52 \pm 2.26^{\mathrm{b}}$ \\
AA2 & $510.46 \pm 34.84^{\mathrm{a}}$ & $637.26 \pm 15.23^{\mathrm{a}}$ & $97.04 \pm 4.45^{\mathrm{a}}$ & $59.62 \pm 1.68^{\mathrm{a}}$ \\
AA3 & $446.38 \pm 29.93^{\mathrm{b}}$ & $525.93 \pm 23.41^{\mathrm{b}}$ & $62.00 \pm 2.67^{\mathrm{b}}$ & $29.59 \pm 2.25^{\mathrm{c}}$ \\
AA4 & $374.40 \pm 25.79^{\mathrm{cd}}$ & $479.72 \pm 34.32^{\mathrm{bc}}$ & $52.44 \pm 3.45^{\mathrm{bc}}$ & $30.60 \pm 2.30^{\mathrm{c}}$ \\
\hline
\end{tabular}

* Each value represents the mean of three replicates. For each parameter of each different letters are significantly different at $p \leq 0.05$ according to LSD test

\section{Discussion}

Salt stress is a major environmental factor which prevents crop plants from attaining their full genetic potential; therefore, salt stress in plants induces several growth limitations. The increase in fresh weight of shoots by $205.1 \%$ (AA1), $809.7 \%$ (AA2), $140 \%$ (AA3), and $115.2 \%$ (AA4) compared with salt treated plants, as well as dry weight of shoot by $431.3 \%$ (AA1), $883.5 \%$ (AA2), 146.3\% (AA3), and 109.6\% (AA4) (Table 1). Generally, all growth parameters effected positively with AA treatment under salt stress condition. Goss (1973) reported the positive effect that amino acids have on growth and indicated that they can be used as an energy and carbon source, when there is a carbohydrate deficiency and the plants amino acids have been determined, via the release of the organic acid and ammonia that originally formed the amino acid. Nahed et al. (2010) reported that it was possible to indirectly explain amino acid regulatory effects, as some amino acids had been observed to affect the development of plants via the influence they had on the biosynthesis of gibberellins. In plant cells, amino acids are a source of nitrogen that is instantly available and can usually be more rapidly used than inorganic nitrogen. Additionally, amino acid conversion into some plant growth regulators may be the result of growth promotion in plants (Afifipour and Khosh-Khui, 2015). Amino acids can directly or indirectly influence the physiological activities in plant growth and development such as exogenous application of amino acids have been reported to modulate the growth, production and quality of tomato in plastic greenhouse (Boras et al., 2011). Also, Sadak et al. (2015) reported that also, amino acids are commonly known as a biostimulant that positively effects plant growth and yield, and significantly reduces 
damage as a result of abiotic stressors, and amino total, as an amino acid source, may have a significant part in the metabolism of plants and assimilation of protein, which is very important in the formation of cells and thus, results in a fresh and dry matter increase.

It is well known that, when transpiration exceeds water absorption, cell turgor falls as relative water content and cell volume decreased and low turgor and RWC slow plant growth and decrease of stomatal conductance (Hammad and Ali, 2014). In this study, concerning the effect of treatment guar plants with amino acids, data in Table 2 showed clearly significant increments in RWC compared to untreated plants at $150 \mathrm{mM} \mathrm{NaCl}$. While RWC values decreased under salt stress between $44 \%$ in salty plants, with the AA applications to RWC demonstrated an increase by $25-60 \%$ in the same conditions. The accumulation of osmolytes in cells aids in the preservation of turgor pressure in the cell and provides protection for cell membranes, metabolic machinery, protein against cell dehydration (Krishnan et al., 2013). Amino acids contribute to osmotic adjustment by acting as osmolytes (Cuin and Shabala, 2007).

Salt stress results in significantly reduced photosynthesis, which is related to the photosynthesizing tissue (i.e. the leaf area) and photosynthetic pigments (Sadak et al., 2015). The pigments declined in plants when salt stress was introduced. In here, the favorable effects of the AA treatments were identified on the chlorophyll components and increased between 8-46 and 37-66\%, compared to salinity (Table 2). The other component carotenoid content increased in guar plants that were treated with AA under salt stress (52-143\% increase). In plants, pigments like carotenoids have various roles, in addition to the specific role they play in photosynthesis, one of which is their involvement in defense mechanisms against oxidative stress (Taibi et al., 2016). It is possible that the increased photosynthetic pigments were the result of the effect of amino acids on metabolism instigation and metabolically processes to increases plant efficiency (Starck, 2005). It seems that the mentioned amino acids were able to enhance the tolerant ability of the wheat against salt stress by increment the photosynthetic pigments (Bahari et al., 2013). Amino acids play a role in increasing the concentration of chlorophyll in plants, resulting in more efficient photosynthesis. Any influence that results in increased photosynthetic pigment levels will subsequently result in increased carbohydrate content. As a significant photosynthetic energy repository, carbohydrates encompass the plant's structural polysaccharides, specifically cellulose, hemicelluloses, lignin, and pectin, which have been deemed as significant structural compounds (El-Ghamry et al., 2009). Additionally, the effect that amino acids have on the total carbohydrate content could be the result of their vital involvement in chlorophyll molecule biosynthesis, which also affects the metabolism of carbohydrates (Talat et al., 2014).

In plants, phenolic and flavonoid compounds also perform many other roles, such as in cell wall structural components, taking part in the developmental process and growth regulation, in addition to defense mechanisms against abiotic and biotic stressors (Taibi et al., 2016). Talat et al. (2014) reported that compounds are some of the most widespread molecules among plant secondary metabolites, and are of great significance in plant development. Flavonoids represent the main and most complex subgroup of polyphenols with a wide array of biological functions including lipid peroxidation inhibition (Taibi et al., 2016). Our results indicated that the utilization of amino acid maintained an important increase in total phenolic, total flavonoid contents and total free amino acid content compared to untreated plants under salt stress (33-77, 16-44, and 53-156\% increase). These results clearly indicate that the amino acid play a stimulatory influence in phenolic accumulation in guar (Table 3). The metabolism of AA has a significant regulatory affect, 
not merely due to AAs as protein constituents, but also due to the potential of free AAs as regulatory and signaling molecules, and energy-associated metabolite precursors, in addition to various secondary metabolites that play a role in the growth of plants and their ability to adaptively respond to numerous stresses (Planchet et al., 2015). Sadiq et al. (2016) explained that abiotic stress causes hydrolysis of proteins into free amino acids, and foliar treatment of antioxidants enhances the biosynthesis of free amino acids and their utilization into protein. As lipid peroxidation is the mostly ascribed symptom to oxidative damage, it is often used as a marker of oxidative stress (Taibi et al., 2016). In this study, lipid peroxidation of guar seedlings increased with salt stress $(189.7 \%$ increases). The results showed that AA treatments reduced the MDA levels, presenting a favorable effect in reducing the oxidative stress emerging from salt stress.

Ion toxicity in plant cells is the result of the salt-stress caused by a significant $\mathrm{Na}^{+}$and $\mathrm{Cl}^{-}$cell influx, as well as the reality that the majority of plants amasses a high concentration of $\mathrm{Na}^{+}$and $\mathrm{Cl}^{-}$ion in their shoots when cultivated under salt stress, which is a significant cause of decreased growth (Parihar et al., 2015; Liang et al., 2018). The uptake of $\mathrm{K}^{+}$and $\mathrm{Ca}^{2+}$ was reduced by $\mathrm{Na}^{+}$in guar under salinity conditions. Sodium concentration increased in plants grown under salinity; however amino acid application significantly reduced $\mathrm{Na}^{+}$concentration in guar leaves. Application of AA resulted in improvement uptake $\mathrm{K}^{+}$and $\mathrm{Ca}^{2+}$ ions. Thereby AA applications counteracted partially or completely the adverse effect of salinity as it increased the accumulation of $\mathrm{K}^{+}$and $\mathrm{Ca}^{2+}$, in the same time it decreased the absorption of $\mathrm{Na}^{+}$and $\mathrm{Cl}^{-}$in guar leaves compared with the corresponding salinity (Table 4). Increased $\mathrm{K}^{+}$concentration and reduced $\mathrm{Na}^{+}$in leaves may be one of the possible mechanisms of increased salinity tolerance by amino acid application in guar plants. Calcium is considered as an important factor for the maintenance of cell membrane integrity and the regulation of ion-transport. $\mathrm{Ca}^{2+}$ is essential for $\mathrm{K}^{+}$vs $\mathrm{Na}^{+}$ion selectivity and membrane integrity (Rady, 2012). Increasing potassium uptake is also a known strategy to counteract the entry of sodium. Rai (2002) indicated that amino acids promoting stomatal opening promoted $\mathrm{K}^{+}$influx into the guard cells while amino acids inhibiting stomatal opening inhibited $\mathrm{K}^{+}$flux into the guard cells. According to these results exogenous amino acid can modulate membrane permeability and ion uptake and apparently this is the major component by which amino acids help in mitigating salt stress effects (Rai, 2002). Sadak et al. (2015) indicated that amino acid has a chelating effect on micronutrient when applied, that make the absorption and transportation of micronutrients inside the plant easier due to its effect on cell membrane permeability. Similarity, exogenous amino acids have been shown to promote $\mathrm{K}^{+}$uptake by $15 \%$ in radish and $\mathrm{Ca}^{++}$uptake by $20-60 \%$ in bean (Rai, 2002).

ROS in plant cells are generated via normal cellular metabolism or stressful environmental conditions such as drought, heavy metals, herbicides, nutrient deficiency, radiation, or salinity. A direct consequence of salinity is the induction of stress and antioxidant enzymes by exposed plants to minimize the damage caused by reactive oxygen species (Amar and Nourredine, 2016). Enzymatic antioxidant defense systems, such as APX, CAT, DHAR, GR, MDHAR, POX, SOD; and non-enzymatic antioxidant defense systems, such as ascorbate, carotenoids, glutathione, glycine betaine, phenolic compounds, polyamines, proline, and sugar (Sen, 2012). In here, responses to AA applications in the salt-stressed medium were examined and researchers reported an increase in antioxidative enzyme activities such as SOD, CAT, GR, and APX. These increases were statistically significant and determined by average $27-48 \%$ ratios (Table 5). Amino acids are important components of antioxidant systems in plants. The 
action of these molecules involves the reduction of free radicals and osmoprotection. Our results showed that, treatment of amino acid had a stimulating effect on antioxidative enzyme activities. Thus, Darwesh (2013) reported that CAT and POD enzymes activity increased with salt treatment, same to be found at amino acid applications, all levels significant were enhanced activity of CAT and POD particular the highest levels of 6.0 $\mathrm{ml} \mathrm{L}-1$ of amino acids treatment.

\section{Conclusion}

Salinity stress led to significant reductions in growth parameters, photosynthetic pigments, seconder metabolites such as total phenolic compounds and flavonoid contents, potassium and calcium concentrations of guar seedlings while induced higher contents of sodium, chlorine, and malondialdehyde. The application of amino acid to salinity condition appeared to be favorable to growth and development, in addition to biochemical and physiological processes of the guar. Therefore, amino acid application has been achieved to be helpful strategy for enhancing the tolerance of the guar plants when grown under salinity conditions. Moreover, $600 \mathrm{mg} \mathrm{L}^{-1}$ amino acid treatment was the stronger effect in alleviating the harmful effect of salt stress compared to the other amino acid applications. The effects of $600 \mathrm{mg} \mathrm{L}^{-1}$ amino acid administration on yield under salt stress conditions can be examined in future studies.

\section{REFERENCES}

[1] Afifipour, Z., Khosh-Khui, M. (2015): Efficacy of spraying a mixture of amino acids on the physiological and morphological characteristics of tuberose (Polianthes tuberosa L.). - International Journal of Horticultural Science and Technology 2(2): 199-204.

[2] Amar, T., Nourredine, Y. (2016): Morphometric variability and biochemical analysis of growth seedlings under salt stress in tomato (Lycopersicon esculentum Mill.) cultivars. Molecular Plant Breeding 7(4): 1-9.

[3] Arnon, D. I. (1949): Copper enzymes in isolated chloroplast: polyphenoloxidase in Beta vulgaris. - Plant Physiology 14: 1-15.

[4] Bahari, A., Pirdashti, H., Yaghubi, M. (2013): The effects of amino acid fertilizers spraying on photosynthetic pigments and antioxidant enzymes of wheat (Triticum aestivum L.) under salinity stress. - International Journal of Agronomy and Plant Production 4(4): 787793.

[5] Batista-Silva, W., Heinemann, B., Rugen, N., Nunes-Nesi, A., Araújo, W. L., Braun, H. P., Hildebrandt, T. M. (2019): The role of amino acid metabolism during abiotic stress release. - Plant, Cell and Environment 42(5): 1630-1644.

[6] Boras, M., Zidan, R., Halloum, W. (2011): Effect of amino acids on growth, production and quality of tomato in plastic greenhouse. - Biological Sciences Series 33(5): 229-238.

[7] Cakmak, I., Marschner, H. (1992): Magnesium defficiency and highlight intensity enhance activities of superoxide dismutase, ascorbate peroxidase and glutathione reductase in bean leaves. - Plant Physiology 98: 1222-1226.

[8] Cuin, T. A., Shabala, S. (2007): Amino acids regulate salinity-induced potassium efflux in barley root epidermis. - Planta 225(3): 753.

[9] Darwesh, R. S. (2013): Improving growth of date palm plantlets grown under salt stress with yeast and amino acids applications. - Annals of Agricultural Sciences 58(2): 247-256.

[10] Dasgan, H. Y., Koc, S. (2009): Evaluation of salt tolerance in common bean genotypes by ion regulation and searching for screening parameters. - Journal of Food, Agriculture and Environment 7(2): 363-372. 
[11] De Freitas, P. A. F., De Souza Miranda, R., Marques, E. C., Prisco, J. T., Gomes-Filho, E. (2018): Salt tolerance induced by exogenous proline in maize is related to low oxidative damage and favorable ionic homeostasis. - Journal of Plant Growth Regulation 37(3): 911924.

[12] El-Din, K. M. G., El-Wahed, M. A. (2005): Effect of some amino acids on growth and essential oil content of chamomile plant. - International Journal of Agriculture and Biology 7: 376-380.

[13] El-Ghamry, A. M., El-Hai, K. A., Ghoneem, K. M. (2009): Amino and humic acids promote growth, yield and disease resistance of faba bean cultivated in clayey soil. Australian Journal of Basic and Applied Sciences 3(2): 731-739.

[14] Goss, J. A. (1973): Amino acid synthesis and metabolism. - Physiology of plants and their cells. Pergamon Press, Inc., New York.

[15] Hammad, S. A., Ali, O. A. (2014): Physiological and biochemical studies on drought tolerance of wheat plants by application of amino acids and yeast extract. - Annals of Agricultural Sciences 59(1): 133-145.

[16] Heath, R. L., Packer, L. (1968): Photoperoxidation in isolated chloroplasts. I. Kinetics and stoichiometry of fatty acid peroxidation. - Archives of Biochemistry and Biophysics 125: 189-198.

[17] Karanlik, S. (2001): Resistance to salinity in different wheat genotypes and physiological mechanisms involved in salt resistance. - Institute of Natural and Applied Sciences, University of Cukurova, Turkey.

[18] Krishnan, S., Laskowski, K., Shukla, V., Merewitz, E. B. (2013): Mitigation of drought stress damage by exogenous application of a non-protein amino acid $\gamma$-aminobutyric acid on perennial ryegrass. - Journal of the American Society for Horticultural Science 138(5): 358-366.

[19] Liang, W., Ma, X., Wan, P., Liu, L. (2018): Plant salt-tolerance mechanism. - Biochemical and Biophysical Research Communications 495(1): 286-291.

[20] Medina-Juárez, L. Á., Molina-Quijada, D., Del Toro Sánchez, C. L., González-Aguilar, G. A., Gámez-Meza, N. (2012): Antioxidant activity of peppers (Capsicum annuum L.) extracts and characterization of their phenolic constituents. - Interciencia 37(8): 588-592.

[21] Molina-Quijada, D. M. A., Medina-Juárez, L. A., González-Aguilar, G. A., RoblesSánchez, R. M., Gámez-Meza, N. (2010): Phenolic compounds and antioxidant activity of table grape (Vitis vinifera L.) skin from northwest Mexico. - CyTA-Journal of Food 8: 57 63.

[22] Nahed, G., Abdel Aziz, A. A., Mazher, M., Farahat, M. M. (2010): Response of vegetative growth and chemical constituents of Thuja orientalis L. plant to foliar application of different amino acids at Nubaria. - Journal of American Science 6(3): 295-301.

[23] Parihar, P., Singh, S., Singh, R., Singh, V. P., Prasad, S. M. (2015): Effect of salinity stress on plants and its tolerance strategies. - Environmental Science and Pollution Research 22(6): 4056-4075.

[24] Patel, A. D., Lalcheta, K., Gill, S. S., Tuteja, N. (2013): Salinity Tolerance of Avicennia officinalis L. (Acanthaceae) from Gujarat Coasts of India. - In: Tuteja, N., Gill, S. (eds.) Climate Change and Plant Abiotic Stress Tolerance. Wiley-VCH Verlag GmbH \& Co. KGaA.

[25] Pathak, R. (2015): Clusterbean: Physiology, Genetics and Cultivation. - Springer.

[26] Planchet, E., Limami, A. M., D'mello, J. P. (2015): Amino acid synthesis under abiotic stress. - In: D’Mello, J. P. H. (ed.) Amino acids in higher plants CAB International.

[27] Rady, M. M. (2012): A novel organo-mineral fertilizer can mitigate salinity stress effects for tomato production on reclaimed saline soil. - South African Journal of Botany 81: 814.

[28] Rady, M. M., Taha, S. S., Kusvuran, S. (2018): Integrative application of cyanobacteria and antioxidants improves common bean performance under saline conditions. - Scientia Horticulturae 233: 61-69. 
[29] Rai, V. K. (2002): Role of amino acids in plant responses to stresses. - Biologia Plantarum 45(4): 481-487.

[30] Sadak, M. S., Abdelhamid, M. T. (2015): Influence of amino acids mixture application on some biochemical aspects, antioxidant enzymes and endogenous polyamines of Vicia faba plant grown under seawater salinity stress. - Gesunde Pflanzen 67(3): 119-129.

[31] Sadiq, M., Akram, N. A., Javed, M. T. (2016): Alpha-tocopherol alters endogenous oxidative defense system in mung bean plants under water-deficit conditions. - Pakistan Journal of Botany 48(6): 2177-2182.

[32] Sarojnee, D. Y., Navindra, B., Chandrabose, S. (2009): Effect of naturally occurring amino acid stimulants on the growth and yield of hot peppers. - Journal of Animal Plant Sciences 5(1): 414-424.

[33] Schubert, S., Läuchli, A. (1990): Sodium exclusion mechanisms at the root surface of two maize cultivars. - In Genetic Aspects of Plant Mineral Nutrition: 183-187.

[34] Sekmen, A. H., Bor, M., Ozdemir, F., Turkan, I. (2013): Current concepts about salinity and salinity tolerance in plants. - In: Tuteja, N., Gill, S. (eds.) Climate Change and Plant Abiotic Stress Tolerance. Wiley-VCH Verlag GmbH \& Co. KGaA.

[35] Sen, A. (2012): Oxidative stress studies in plant tissue culture. - Antioxidant Enzyme 3: 59-88.

[36] Singleton, V. L., Orthofer, R., Lamuela-Raventós, R. M. (1999): Analysis of total phenols and other oxidation substrates and antioxidants by means of folin-ciocalteu reagent. Methods in Enzymolog 299: 152-178.

[37] Starck, Z. (2005): Growing assistant: Application of growth regulators and biostimulators in modern plant cultivation. - Rolnik Dzierawca 2: 74-76.

[38] Taibi, K., Taibi, F., Abderrahim, L. A., Ennajah, A., Belkhodja, M., Mulet, J. M. (2016): Effect of salt stress on growth, chlorophyll content, lipid peroxidation and antioxidant defence systems in Phaseolus vulgaris L. - South African Journal of Botany 105: 306-312.

[39] Talaat, I. M., Khattab, H. I., Ahmed, A. M. (2014): Changes in growth, hormones levels and essential oil content of Ammi visnaga $\mathrm{L}$. plants treated with some bioregulators. - Saudi Journal of Biological Sciences 21(4): 355-365.

[40] Wu, G. Q., Feng, R. J., Li, S. J., Du, Y. Y. (2017): Exogenous application of proline alleviates salt-induced toxicity in sainfoin seedlings. - The Journal of Animal and Plant Sciences 27(1): 246-251.

[41] Yemm, E. W., Cocking, E. C. (1955): The determination of amino acids with ninhydrin. Analyst 80: 209-214. 